\title{
Safety of the patient in an emergency situation: perceptions of the nursing team
}

\author{
Segurança do paciente em situação de emergência: percepções da equipe de enfermagem \\ Seguridad del paciente en situación de emergencia: percepciones del equipo de enfermería
}

Andréa Tayse de Lima Gomes'
ORCID: 0000-0003-0505-5783

Marcos Antônio Ferreira Jr" ORCID: 0000-0002-9123-232X

Pétala Tuani Candido Oliveira Salvador' ORCID: 0000-0002-3208-6270

Manacés dos Santos Bezerril' ORCID:0000-0002-9003-2334

Flávia Barreto Tavares Chiavone' ORCID:0000-0002-7113-2356

Viviane Euzébia Pereira Santos' ORCID:0000-0001-8140-8320

'Universidade Federal do Rio Grande do Norte. Natal, Rio Grande do Norte, Brasil.

"Universidade Federal do Mato Grosso do Sul. Campo Grande, Mato Grosso do Ssul, Brasil.

How to cite this article:

Lima Gomes AT, Ferreira Jr MA, Salvador PTCO, Bezerril MS, Chiavone FBT, Santos VEP. Safety of the patient in an emergency situation: perceptions of the nursing team. Rev Bras Enferm. 2019;72(3):753-9. doi: http://dx.doi.org/10.1590/0034-7167-2018-0544

Corresponding Author: Andréa Tayse de Lima Gomes E-mail: andrea.tlgomes@gmail.com

Submission: 06-28-2018 Approval: 02-12-2019

\section{ABSTRACT}

Objective: To know the perception of nursing professionals about the essential aspects to provide safe care to polytraumatized patients in emergency services. Method: Descriptive and mixed study, performed with a focus group and projective techniques. The sample was made of seven nursing professionals. Data analysis took place through the Interface de R pour Analyses Multidimensionnelles de Textes et de Questionneires and SPSS 22.0 softwares. Results: Based on the analysis of participants' speeches, three content partitions emerged in the Descending Hierarchical Classification. 1) Structure: need for changes; 2) The process: safe actions by the nursing team; and 3) Care free from damage as the sought result. Conclusion: Patient safety in emergency situations must rely on a proper environment and an organized sector, good conditions to transport patients, use of routines and protocols, identification and organization of the beds. Descriptors: Patient Safety; Quality of Health Care; Emergencies; Multiple Trauma; Nursing.

\section{RESUMO}

Objetivo: Conhecer a percepção dos profissionais de enfermagem quanto aos aspectos essenciais para a prestação de um cuidado seguro ao paciente politraumatizado no serviço de emergência. Método: Estudo descritivo e misto, realizado por meio de grupo focal e técnicas projetivas. A amostra foi composta por sete profissionais de enfermagem. A análise dos dados ocorreu por meio dos softwares Interface de R pour Analyses Multidimensionnelles de Textes et de Questionneires e SPSS 22.0. Resultados: Com base na análise das falas dos participantes, três partições de conteúdo emergiram na Classificação Hierárquica Descendente: 1) Estrutura: necessidade de mudanças; 2) O processo: segurança nas ações da equipe de enfermagem; e 3) A assistência livre de danos como resultado almejado. Conclusão: A segurança do paciente em situação de emergência deve ser pautada na adequação do ambiente e organização do setor, condições de transporte do paciente, uso de rotinas e protocolos, identificação e organização do leito.

Descritores: Segurança do Paciente; Qualidade da Assistência à Saúde; Emergências; Traumatismo Múltiplo; Enfermagem.

\section{RESUMEN}

Objetivo: Conocer la percepción de los profesionales de enfermería en cuanto a los aspectos esenciales para la prestación de un cuidado seguro al paciente politraumatizado en el servicio de emergencia. Método: Estudio descriptivo y mixto, realizado por medio de un grupo focal y técnicas proyectivas. La muestra fue compuesta por siete profesionales de enfermería. El análisis de los datos ocurrió por medio de los softwares de Rpour Analyses Multidimensionnelles de Textes et de Questionneires y el SPSS 22.0. Resultados: Con base en el análisis de las hablas de los participantes, tres particiones de contenido emergieron en la Clasificación Jerárquica Descendente: 1) Estructura: necesidad de cambios; 2) El proceso: seguridad en las acciones del equipo de enfermería; y 3) La asistencia libre de daños como resultado deseado. Conclusión: La seguridad del paciente en situación de emergencia debe ser pautada en la adecuación del ambiente y organización del sector, las condiciones de transporte del paciente, el uso de rutinas y protocolos, además de la identificación y organización del lecho.

Descriptores: Seguridad del Paciente; Calidad de la Atención de Salud; Urgencias Médicas; Traumatismo Múltiple; Enfermería. 


\section{INTRODUCTION}

Traumatic injuries, most notably traffic accidents and violence, are serious public health problems, accounting for the death of approximately 5.8 million people each year. This reality accounts for about $50 \%$ of deaths worldwide, more than the number of fatalities due to malaria, tuberculosis and human immunodeficiency virus (HIV)/Acquired Immunodeficiency Syndrome (AIDS) combined ${ }^{(1-4)}$.

Given this scenario, the vulnerability of severely injured patients is clear and, too often, critical conditions cause an unpredictable course of injury progression. These people are physiologically unstable and at greater risk of developing adverse events ${ }^{(5)}$.

The first hour or "golden hour" following trauma offers the greatest possibility of intervention when there is risk of death for polytraumatized patients. Therefore, rapid and early actions can minimize the onset of secondary injuries and reduce morbidity in patients with multiple severe traumas, in order to increase survival rates with as few sequelae as possible ${ }^{(6)}$.

In this situation, delays in the treatment of traumatic injuries and acute diseases increase morbidity and mortality and a greater possibility of adverse events in emergency care exists ${ }^{(7)}$. Therefore, the health service must have adequate and qualified staff to ensure that the care provided is safe and of high quality.

This safe care refers to the set of measures taken to prevent and/ or minimize harm to patients during the process of using health services. Meanwhile, safety is an important dimension of quality, and is defined as the right of people to have the risk of unnecessary harm associated with health care reduced to an acceptable minimum ${ }^{(8-9)}$, especially when it comes to individuals with multiple traumas assisted in emergency units, since they are already at imminent risk of death.

However, the quality of health systems, technologies and verification processes to support patient safety in practice can be variable, unsafe and not effective. This fact is reiterated whereas Emergency professionals routinely engage in dealing with high workloads associated with attempting to manage a variety of other human factors that may compromise the quality of care provided and patient safety. The factors vary from overcrowding and deficiencies in the distribution of financial resources; poor work process (system failures); organizational constraints (response to contractual incentives and increased patient demand); availability of limited material and structural resources; to external political pressures (meeting the goals for patient access) ${ }^{(10-11)}$.

Thus, the quality of care is not an abstract attribute. It can be constructed by the assessment of health services, linked to the analysis of the structure, the work processes and their results, to establish a health evaluation model based on structure, process and outcome components, as proposed by Avedis Donabedian ${ }^{(11-14)}$.

In the light of this, Donabedian describes that the structure relates to the relatively stable aspects, such as: professionals, instruments and resources they have available, and places and models of work organization. The process refers to the set of activities performed by professionals for patients and their responses, and includes diagnostic, therapeutic and preventive decision-making actions. The results link the effectiveness and efficiency of actions and the level of patient satisfaction ${ }^{(14-15)}$.

Thus, available, qualified, material and human resources must be enough to provide safe and harmless nursing care, especially in emergency services. These are places where care must be provided quickly, effectively and efficiently.

To guide present research, the following question was asked: What is the perception of nursing professionals regarding essential aspects to ensure safe care to polytraumatized patients in emergency services?

\section{OBJECTIVE}

To know the perception of nursing professionals about the essential aspects to provide safe care to polytraumatized patients in emergency services.

\section{METHODS}

\section{Ethical aspects}

This study was previously submitted to the Research Ethics Committee of the Universidade Federal do Rio do Norte, which approved the development of the study.

\section{Research design, place and period}

This is a descriptive, cross-sectional and mixed-approach study. The focus group technique was used. Research was conducted at a first-aid emergency room in traumatic emergencies in the Northeast Region of Brazil, in October 2015.

\section{Population, sample, inclusion and exclusion criteria}

The nursing professionals working at the institution were enrolled as study subjects. The sample was selected according to the following inclusion criteria: being a nurse or a licensed practical nurse and acting or having acted for at least six months in the polytrauma sector of the emergency room.

Research was spread through invitation flyers distributed by the emergency departments. After that, 14 professionals registered and 10 attended the day of data collection. Based on the inclusion criteria, seven nursing professionals became part of the sample, in order to comply with the parameter recommended by the literature that focus groups must have from six to fifteen participants ${ }^{(16-18)}$.

\section{Study protocol}

To guarantee the anonymity of information form research participants, the nurses were identified with the letter " $\mathrm{N}$ " followed by the numbers 1 and 2 (N1 and N2), and the licensed practical nurses with the letter " $L$ " followed by the numbers from 1 to 5 ( $L 1$ to $L 5$ ).

After the instructions were given, participants signed the Informed Consent Term. The data were then collected by using a questionnaire related to sociodemographic and professional data and the use of projective techniques.

Nonetheless, Sandplay therapy and humanistic experiential pedagogy were used, consisting of a strategy executed with the "assembling-writing-speaking" triad, based on the guiding question: What is the perception of nursing professionals regarding essential aspects to ensure safe care to polytraumatized patients 
Safety of the patient in an emergency situation: perceptions of the nursing team Lima Gomes AT, Ferreira Jr MA, Salvador PTCO, Bezerril MS, Chiavone FBT, Santos VEP.

in emergency services? Namely: 1) "assembling" refers to build a setting with the use of available materials (miniatures); 2) "writing", to the description of the setting built in a research instrument that contributed to the analysis of speeches of the subjects surveyed; and, 3) "speaking", to representations, to share ideas, opinions and perceptions ${ }^{(19)}$.

\section{Analysis of results, and statistics}

The transcription of the qualitative content, speech and writing, was submitted to the lexicographic analysis in the software named Interface de R pour Analyses Multidimensionnelles de Textes et de Questionneires (IRAMUTEQ). The quantitative data were typed and organized in the program Microsoft Excel 2010 and analyzed descriptively by the software SPSS version 22.0.

For that, the Descending Hierarchical Classification and the similitude analysis as methods of data treatment were used. Thus, each text was characterized by the variables of interest: professional category (licensed practical nurse or nurse), gender and time of work in the emergency sector, for which the level of significance of $\mathrm{p} \leq 0.0001$ was considered. The inclusion criteria as for the elements in their respective classes in the dendogram were: frequency greater than twice the average number of occurrences in the corpus and association with the class determined by the chi-square value equal to or greater than 3.84 ( $p$ value $\leq 0.05$ ) and significance of $95 \%{ }^{(20)}$.

This study is part of larger research, which sought to create and validate the content and appearance of three graphic protocols for to assess nursing care for polytraumatized patients in the emergency department. Therefore, this article refers to the construction phase of these instruments, seeking to know the perception of nursing professionals, who deal daily with the weaknesses and potentialities experienced in the services that provide this type of care. These factors have a direct influence on patient safety to understand the aspects that professionals believe are essential for ensuring safe care to patients with multiple traumas at imminent risk of death.

\section{RESULTS}

The focus group included seven nursing professionals, most of whom were women ( $n=5,71.4 \%)$, aged from 26 to 57 , with an average of 40.86 years old (+/- 11.8$)$, married $(n=5,71.4 \%)$, living in the state capital of Rio Grande do Norte, Natal ( $n=5,71.4 \%)$. At the time of data collection, three professionals (42.9\%) were in the intensive care unit of the emergency room, one (14.3\%) in the health care center for workers and three (42.9\%) in the emergency room (polytrauma). Table 1 presents the professional characterization of the focus group participants.

Regarding postgraduate training, one nurse (14.3\%) specialized in Occupational health nursing and one licensed practical nurse (14.3\%) in Occupational safety and health.

As for the analysis of the corpus text of the participants'speeches, the occurrence of 1,381 words was found, allocated in 533 types to totalize an average of three words for each type. This was a cut-off point to include elements in the dendogram and in the analysis of similarities, which is twice the average frequency, that is, six.
Table 1 - Professional characterization of the focus group participants, $2015(\mathrm{~N}=7)$

\begin{tabular}{|c|c|c|c|c|}
\hline PROFESSIONAL CHARACTERIZATION & $\mathbf{n}$ & $\%$ & Average & $\begin{array}{l}\text { Standard } \\
\text { deviation }\end{array}$ \\
\hline \multicolumn{5}{|l|}{ Professional category } \\
\hline Nurse & 2 & 28.6 & \multirow{2}{*}{ - } & \multirow{2}{*}{-} \\
\hline Licensed practical nurse & 5 & 71.4 & & \\
\hline \multicolumn{5}{|l|}{ Time since graduated } \\
\hline Up to 10 years & 2 & 28.6 & \multirow{2}{*}{15.6} & \multirow{2}{*}{7.8} \\
\hline More than 10 years & 5 & 71.4 & & \\
\hline \multicolumn{5}{|l|}{ Time working in the hospital environment } \\
\hline Up to 10 years & 2 & 28.6 & \multirow{2}{*}{15.1} & \multirow{2}{*}{8.4} \\
\hline More than 10 years & 5 & 71.4 & & \\
\hline \multicolumn{5}{|l|}{ Time working in the emergency department } \\
\hline Up to 10 years & 4 & 57.1 & \multirow{2}{*}{11.3} & \multirow{2}{*}{9.1} \\
\hline More than 10 years & 3 & 42.9 & & \\
\hline \multicolumn{5}{|l|}{ Time working in the current health unit } \\
\hline Up to 10 years & 5 & 71.4 & \multirow{2}{*}{7.0} & \multirow{2}{*}{9.3} \\
\hline More than 10 years & 2 & 28.6 & & \\
\hline TOTAL & 7 & 100.0 & - & - \\
\hline
\end{tabular}

Based on the Descending Hierarchical Classification, 38 text segments were analyzed, in which $78.95 \%$ of the corpus was classified for the elaboration of the seven classes from the content partitions (Chart 1).

The first partition resulting from the analysis of the textual corpus provided an understanding of the need for structural changes in emergency services. This aims at contributing to provide safe care, which encompassed two classes: the importance of the adequacy of the environment so that care (class 1) and (re) organization of the emergency department as a contributing factor for the safety of patients and professionals (class 2).

As for the specific vocabulary of class 1 , which makes up $13.3 \%$ of the quantitative analyzed, the significant words $(p \leq 0.05)$ evidenced were: to have, to arrive and no, showing the relevance of the availability of human and material resources in quantity and quality for safe emergency care.

Meanwhile, professionals are concerned with the structure of emergency services both in relation to the inherent aspects of human resources and the materials available in the department, according to the speech of $\mathrm{L} 1$ :

(...) more than anything, we need more employees (...) When three or four emergency patients, even intubated patients, arrive it is common to see professionals of the emergency mobile service wandering around waiting for the department's team to find a proper place (...) There's no space, no breathing tubes, which means that structure urges for improvement. (L1)

The restlessness of professionals from emergency services regarding lack of structure is also clear in class 2 (13.3\%). In this class, the nursing team pointed to the de-characterization of the polytrauma department. It allocated traumatic emergency beds to patients with clinical comorbidities due to lack of stretchers and oxygen points in other departments of the hospital. This results in overcrowding of the emergency department and deficient care for trauma patients, as explained by L5:

Patients stay in the emergency department and other specialties' departments for a long time. You see a trauma department filled more by cases of medical clinic than of trauma. (L5) 
Safety of the patient in an emergency situation: perceptions of the nursing team Lima Gomes AT, Ferreira Jr MA, Salvador PTCO, Bezerril MS, Chiavone FBT, Santos VEP.

Chart 1 - Dendogram classes related to the textual corpus analysis, 2015

\begin{tabular}{|c|c|c|c|c|c|}
\hline \multirow{2}{*}{ Partition } & \multirow[b]{2}{*}{ Class } & \multicolumn{3}{|c|}{ Lexicographic analysis } & \multirow{2}{*}{$\begin{array}{l}\text { Significance level } \\
\text { between variables* }\end{array}$} \\
\hline & & Word & $\%$ & $\begin{array}{c}X^{2} \\
p \text { value }\end{array}$ & \\
\hline \multirow{2}{*}{$\begin{array}{l}\text { Structure: } \\
\text { need for } \\
\text { changes }\end{array}$} & $\begin{array}{c}1 \text { - Importance } \\
\text { environment } \\
\text { adequacy in } \\
\text { emergency care } \\
(13.3 \%)\end{array}$ & $\begin{array}{c}\text { To be } \\
\text { To have } \\
\text { To arrive } \\
\text { No }\end{array}$ & $\begin{array}{l}25.0 \\
36.4 \\
37.5 \\
42.9\end{array}$ & $\begin{array}{l}0.124 \\
0.004 \\
0.018 \\
0.008\end{array}$ & $\begin{array}{l}\text { Licensed practical } \\
\text { nurse who have } \\
\text { been working in } \\
\text { the emergency } \\
\text { department for a } \\
\text { maximum of five years }\end{array}$ \\
\hline & $\begin{array}{l}\text { 2-The (re) } \\
\text { organization of } \\
\text { the emergency } \\
\text { department as } \\
\text { a reflex of safety } \\
(13.3 \%)\end{array}$ & $\begin{array}{l}\text { To need } \\
\text { In } \\
\text { One }\end{array}$ & $\begin{array}{l}44.4 \\
21.0 \\
25.0\end{array}$ & $\begin{array}{l}0.001 \\
0.102 \\
0.124\end{array}$ & $\begin{array}{l}\text { There was no } \\
\text { significant difference } \\
\text { between variables }\end{array}$ \\
\hline \multirow{3}{*}{$\begin{array}{l}\text { The process: } \\
\text { safe actions } \\
\text { by the nursing } \\
\text { team }\end{array}$} & $\begin{array}{c}3 \text { - The role of safe } \\
\text { transportation } \\
\text { in emergency } \\
\text { situations }(13.3 \%)\end{array}$ & $\begin{array}{l}\text { To be } \\
\text { How } \\
\text { To go }\end{array}$ & $\begin{array}{l}25.0 \\
33.3 \\
25.0\end{array}$ & $\begin{array}{l}0.124 \\
0.008 \\
0.124\end{array}$ & $\begin{array}{l}\text { Licensed practical } \\
\text { nurses who have } \\
\text { been working for } \\
\text { more than } 20 \text { years } \\
\text { in the emergency } \\
\text { department }\end{array}$ \\
\hline & $\begin{array}{l}\text { 4- The contribution } \\
\text { of routines and } \\
\text { protocols for } \\
\text { patient safety } \\
(16.7 \%)\end{array}$ & $\begin{array}{l}\text { To be } \\
\text { Patient } \\
\text { To go } \\
\text { Him }\end{array}$ & $\begin{array}{l}45.5 \\
29.4 \\
33.3 \\
37.5\end{array}$ & $\begin{array}{l}0.001 \\
0.032 \\
0.045 \\
0.064\end{array}$ & $\begin{array}{c}\text { Men professionals } \\
\text { who work in } \\
\text { the emergency } \\
\text { department }\end{array}$ \\
\hline & $\begin{array}{c}5 \text { - The proactivity } \\
\text { of professionals } \\
\text { as a safety factor } \\
(16.7 \%)\end{array}$ & $\begin{array}{l}\text { One } \\
\text { To have } \\
\text { To be }\end{array}$ & $\begin{array}{l}25.0 \\
36.4 \\
36.4\end{array}$ & $\begin{array}{l}0.124 \\
0.004 \\
0.004\end{array}$ & $\begin{array}{l}\text { There was no } \\
\text { significant difference } \\
\text { between variables }\end{array}$ \\
\hline \multirow[b]{2}{*}{$\begin{array}{l}\text { Care free from } \\
\text { damage as the } \\
\text { sought result }\end{array}$} & $\begin{array}{c}6 \text { - The singular and } \\
\text { multifaceted look } \\
\text { for patient safety } \\
(13.3 \%)\end{array}$ & $\begin{array}{c}\text { To represent } \\
\text { To go }\end{array}$ & $\begin{array}{l}44.4 \\
25.0\end{array}$ & 0.001 & $\begin{array}{l}\text { There was no } \\
\text { significant difference } \\
\text { between variables }\end{array}$ \\
\hline & $\begin{array}{c}7 \text { - Patient } \\
\text { safety: an issue } \\
\text { of management } \\
(16.7 \%)\end{array}$ & $\begin{array}{c}\text { To represent } \\
\text { To need } \\
\text { How } \\
\text { Of }\end{array}$ & $\begin{array}{r}55.6 \\
44.4 \\
33.3 \\
22.7\end{array}$ & $\begin{array}{l}0.0001 \\
0.007 \\
0.045 \\
0.139\end{array}$ & $\begin{array}{l}\text { Nurses who have } \\
\text { been work from } \\
\text { six to twenty years } \\
\text { in the emergency } \\
\text { department }\end{array}$ \\
\hline
\end{tabular}

Note:* $p<0.0001$.

The second partition, which included classes 3, 4 and 5, embraces the nursing care process. It refers to the performance of the nursing team assignments to provide safe care to patients in an emergency.

Thus, class 3 (13.3\%) addressed the great importance of safety when transporting patients in the prehospital and hospital facilities, to prevent falls-related injuries, according to the speech given by N2:

(...) care already starts in the pre-hospital phase, that is, how are patients being rescued and how their transport will be. The transportation inside the hospital is also important. (N2)

Likewise, class 4 is also related to the care process of the nursing team in emergency care when portraying the contribution of routines and protocols to patient safety. This class represented $16.7 \%$ of the text segments analyzed, based on the terms to be, patient and to go. Professionals emphasize how wellstructured and applied routines and protocols in emergency services can be of great value to the effectiveness of safe care:

(...) So, the routine must be straightforward. Patients arrive, puncture is performed, adornments are taken off, they put on proper clothes; professionals see where and how to refer patients, what is the flow to send them to examination and call the lab. (N2)

In addition, class 5 (16.7\%) portrays the professionals'observation regarding the care process in the emergency department, especially the words to have and to be. The nursing team considered the previous organization of the space for the adequate and safe care of emergency patients, as reported by $L 1$ :

Test tubes must be ready for exam collection; there should be a bed identified so that when families arrive at the reception and ask if they already know where the patients are, they do. Beds are normally not identified. (L1)

The third content partition emphasized the understanding of what the nursing team expects as a result from the care provided, a perception that can be inferred from the lexicographic analysis of classes $6(13.3 \%)$ and 7 (16.7\%).

Class 6 allows the understanding expressed by nursing professionals regarding the importance of looking at patients as unique and complex beings, in order to meet the individual needs of each one in a safe way. This action contributes substantially to a positive result regarding patient safety, as discussed by N2:

(...) We know that sometimes patients are hospitalized and undernourished because of the food issue. (N2)

Finally, class 7 was significantly $(p \leq 0.0001)$ related to nurses working between six and twenty years in the emergency department, and addressed how efficient management can contribute to patient safety and emergency services, as it points N2:

To achieve patient safety, it is generally necessary to analyze costs (...) The financing part and how is this entire structure being used (...) I used the stretcher here with the patient, representing all the 
part of equipment that we will need, which in many moments we do not have, making care unsafe, such as stretchers without grilles, mattresses of poor quality (...) Water is also a problem, remembering nonclinical risks, such as water treatment, which are the conditions of this water that we are using in a general way, the issue of air conditioning, air conditioning cleaning. (N2)

Figure 1 represents the analysis of similarities, which synthesizes the classified expressions referring to the perception of the nursing team about aspects to be contemplated in the protocol to evaluate structure, process and outcome of the emergency department.

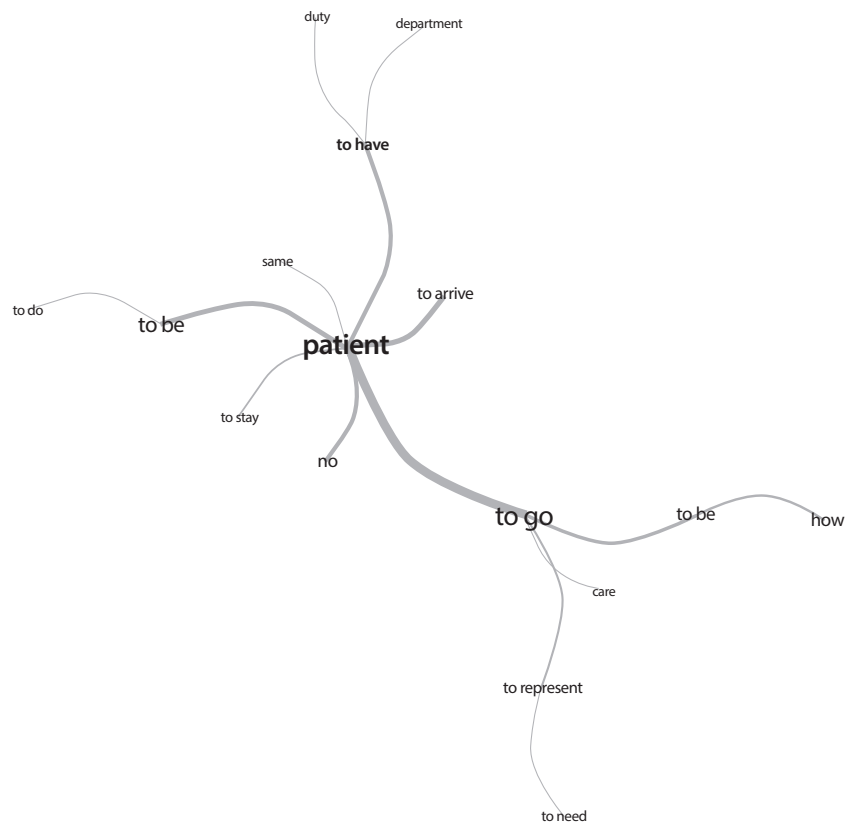

Figure 1 - Analysis of similarity of the textual corpus, 2015

According to Figure 1, the expressions "to go" and "patient" show the relation with the safe performance of the nursing care process to achieve a good results, that is, the provision of care free from damage. Therefore, the links with the expression "to have" represent the need for structural changes in the emergency department to contribute to patient safety.

As for the lines linking the words, it is clear that "patient" is more closely related with the expressions "to go", "to arrive", "to have", "to be" and "no", expressed by the analysis of similarity to the detriment of other links. The strong connection between words synthesizes the perception of the subjects of research, and evidence significant co-occurrence among words.

\section{DISCUSSION}

The professionals participating in this study were concerned about the available structure, considering that current reality contributes substantially to unsafe care. In this sense, the adequacy of the physical structure and the logistics of the emergency department interfere both in the quality of healthcare and in the performance of teams, whether or not they have good working conditions, such as: environmental suitability, (re) structuring of the physical plant and availability of materials and equipment, enough human resources and proper professional training ${ }^{(21-22)}$.

Given this reality, a study conducted with 15 nursing professionals from the emergency unit of a general hospital showed that structural problems also directly interfere with nursing care such as hygiene/comfort and skin integrity. Professionals reported the difficulty in carrying out basic care, such as bathing and change of position, since accommodation on stretchers makes it impossible to provide adequate and safe care ${ }^{(23)}$.

Moreover, in this study, focus group participants emphasized the influence of work overload resulting from insufficient human resources for poor quality of care and patient unsafety. Accordingly, some authors ${ }^{(24-25)}$ acknowledge that adequate nursing staff, with lower patient/professional rates, helps to reduce the incidence of adverse events, such as infections and falls form beds.

Another aspect highlighted by the focus group participants was the de-characterization of the hospital's multi-trauma (emergency room) department. This unit, which should be provisional, where patients should remain for short periods, started to function as an inpatient unit, due to the unavailability of bed in the hospitalization units. Seen this, basic human needs (sleep, rest, eat food and perform body hygiene) are compromised by the excessive demand for care and inadequate infrastructure conditions to perform care activities ${ }^{(26-27)}$.

Regarding safety in the care process of the nursing team, professionals pointed out the importance of safe transportation in both prehospital and hospital care. Therefore, some care is needed to ensure the hemodynamic stability and physical integrity of patients, such as the use of protective measures (grids and safety belts) and increased vigilance when transporting overweight and elderly people, polytraumatized and sedated patients ${ }^{(28-29)}$.

The contribution offered by implementing routines and protocols for safe care in the emergency department was another point discussed by the nursing professionals in this study. However, some authors ${ }^{(30)}$ consider that besides the implementation of new routines and protocols that seek to increase patient safety in the emergency service, the importance of developing educational support strategies and follow-up management actions with the purpose of sustaining safe and evidence-based practices must be respected, such as: continuing education and encouragement to the effectiveness of a the culture of safety.

In addition, the focus group participants highlighted how the proactivity of the nursing team can contribute to patient safety regarding the organization and identification of beds before patients arrive at imminent risk of death in the hospital.

This reality is reiterated when considering that the nonconformities in the identification of patients are pointed out as a worrying factor in health care $^{(31)}$. This fact shows that misidentification leads to a series of adverse events or errors during care.

Finally, the participants of present research explained that the desired result, which consists of providing care free form damage, can be achieved when professionals observe the singular reality and the individual needs of each patient. It is essential that service management be proactive when providing resources needed to develop care.

Therefore, safe care requires efficient and cost-effective management as to cost planning, availability of proper materials such as stretchers with adequate grids and mattresses, and clean and treated water to contribute to safe care. In this way, nurses 
are not only responsible for patient care, but also for training and qualifying nursing professionals, managing materials and supplies, articulating with other Health professionals and administrating the organization, patient and family orientation to promote a multiprofessional management for patients ${ }^{(32-33)}$.

\section{Study limitations}

The limitations of this study were the predominantly qualitative methodological approach and the involvement of professionals from only one local health service, which makes it difficult to generalize results.

\section{Contributions to the Nursing, Health or Public Policy fields}

Spreading the results of this study aims to foster nursing professionals and managers to reflect on the care safety provided to patients with multiple traumas in the emergency department. Nonetheless, research allowed the construction of three graphic protocols, which, after validation, will support the assessment of the safety of polytrauma patients treated at the hospital emergency service.

The application of these instruments in care services to polytrauma patients with imminent risk of death, elaborated with basis in national and international scientific publications and in the experience of professionals working in the area, contributes to the evaluation of the real situation of safe care provided and analysis of the root cause of potential factors generating unsafety and harm to patients. The goal is to seek solutions to reduce deaths due to adverse events related to health care.
Research contributes significantly to Nursing by supporting the construction of three graphic protocols based on the reality expressed and reflected by professionals form the area, who daily experience all the difficulties present in emergency services, which can directly interfere with the patient (un) safety.

\section{CONCLUSION}

Essential aspects to ensure safe care to patients who suffered multiple traumas in emergencies related to the structure are: suitability of the environment and organization of the department as for the exclusivity of beds for patients in situations of traumatic emergencies, since it is a department to care for polytrauma patients; availability of human and material resources in proper quality and quantity.

Regarding the process, professionals emphasized the importance of safety during the transportation of patients, with a view to adequate care to prevent falls; the use of routines and protocols in the department; and the identification and organization of beds before patients arrive at the hospital.

Finally, to achieve the desired results, in the care free from damage, patient care must be provided in compliance with the singularity and the multifaceted reality of each patient, besides the management support, which must be operative and effective in health services.

\section{FUNDING/ACKNOWLEDGEMENT}

Special thanks to CAPES for granting social demand scholarship, Master level.

\section{REFERENCES}

1. Lendrum RA, Lockey DJ. Trauma system development. Anaesthesia [Internet]. 2013 [cited 2016 Nov 28];68(Suppl 1):30-9. Available from: https://dx.doi.org/10.1111/anae.12049

2. World Health Organization (WHO). World Health Statistics 2011 [Internet]. Geneva: WHO; 2011 [cited 2016 Nov 28]. Available from: http:// www.who.int/gho/publications/world_health_statistics/EN_WHS2011_Full.pdf?ua=1

3. Parker M, Magnusson C. Assessment of trauma patients. Int J Orthop Trauma Nurs [Internet]. 2016 [cited 2018 Jun 06];21:21-30. Available from: https://doi.org/10.1016/j.ijotn.2015.10.002

4. Biz C, Buffon L, Marin R, Petrova N. Orthopaedic nursing challenges in poly-traumatised patient management: a critical analysis of an orthopaedic and trauma unit. Int J Orthop Trauma Nurs [Internet]. 2016 [cited 2018 Jun 06];23:60-71. Available from: https://doi. org/10.1016/j.ijotn.2016.04.003

5. Alzghoul MM. The experience of nurses working with trauma patients in critical care and emergency settings: a qualitative study from scottish nurses' perspective. Int J Orthop Trauma Nurs [Internet]. 2014 [cited 2018 Jul 30];18(1):13-22. Available from: https://doi. org/10.1016/j.ijotn.2013.04.004

6. Groenestege-Kreb DT, Maarseveen OV, Leenen L. Trauma team. Br J Anaesth [Internet]. 2014 [cited 2018 Jul 30];113(2):258-65. Available from: https://doi.org/10.1093/bja/aeu236

7. Calvello EJB, Broccoli M, Risko N, Theodosis C, Totten VY, Radeos MS, et al. Emergency care and health systems: consensus-based recommendations and future research priorities. Acad Emerg Med [Internet]. 2013 [cited 2018 Jul 30];20(12):1278-88. Available from: https://doi.org/10.1111/acem.12266

8. Freitas JS, Silva AEBC, Minamisava R, Bezerra ALQ, Sousa MRG. Quality of nursing care and satisfaction of patients attended at a teaching hospital. Rev Lat Am Enfermagem [Internet]. 2014 [cited 2018 Jun 06];22(3):454-60. Available from: https://doi. org/10.1590/0104-1169.3241.2437

9. Capucho HC, Cassiani SHB. The need to establish a national patient safety program in Brazil. Rev Saude Publica [Internet]. 2013 [cited 2018 Jun 06];47(4):1-8. Available from: https://doi.org/10.1590/S0034-8910.2013047004402 
Safety of the patient in an emergency situation: perceptions of the nursing team Lima Gomes AT, Ferreira Jr MA, Salvador PTCO, Bezerril MS, Chiavone FBT, Santos VEP.

10. Bowie P, Ferguson J, MacLeod M, Kennedy S, Wet C, McNab D, et al. Participatory design of a preliminary safety checklist for general practice. Br J Gen Pract [Internet]. 2015 [cited 2018 Jul 30];65(634):e330-43. Available from: https://doi.org/10.3399/bjgp15X684865

11. Bowie P, Halley L, McKay J. Laboratory test ordering and results management systems: a qualitative study of safety risks identified by administrators in general practice. BMJ Open [Internet]. 2014 [cited 2018 Jul 30];4:e004245. Available from: https://doi.org/10.1136/ bmjopen-2013-004245

12. Donabedian A. The quality of medical care: how can it be assessed? JAMA [Internet]. 1988 [cited 2016 Nov 28];260(12):1743-8. Available from: http://dx.doi.org/10.1001/jama.1988.03410120089033

13. Morais AS, Melleiro MM. [The quality of nursing care at an emergency unit: the patient's perception]. Rev Eletr Enf [Internet]. 2013 [cited 2016 Nov 28];15(1):112-20. Available from: http://dx.doi.org/10.5216/ree.v15i1.15243 Portuguese.

14. Donabedian A. Basic approaches to assessment: structure, process and outcome. In: Donabedian A. Explorations in Quality Assessment and Monitoring. Ann Arbor (MI): Health Adiministration Press; 1980.

15. Reis CT, Martins M, Laguardia J. [Patient safety as a dimension of the quality of health care - a look at the literature]. Ciênc Saude Colet [Internet]. 2013 [cited 2016 Nov 28];18(7):2029-36. Available from: http://dx.doi.org/10.1590/S1413-81232013000700018

16. Backes DS, Colomé JS, Erdmann RH, Lunardi VL. Grupo focal como técnica de coleta e análise de dados em pesquisas qualitativas. Mundo Saude [Internet]. 2011 [cited 2016 Dec 02];35(4):438-42. Available from: http://bvsms.saude.gov.br/bvs/artigos/grupo_focal_como_tecnica_ coleta_analise_dados_pesquisa_qualitativa.pdf

17. Kinalski DDF, Paula CC, Padoin SMM, Neves ET, Kleinubing RE, Cortes LF. Focus group on qualitative research: experience report. Rev Bras Enferm [Internet]. 2017 [cited 2018 Jun 06];70(2):424-9. Available from: http://dx.doi.org/10.1590/0034-7167-2016-0091

18. Dall'agnol CM, Trench MH. [Using focus group as a methodologic approach in nursing research]. Rev Gaúcha Enferm [Internet]. 1999 [cited 2018 Jun 06];20(1):5-25. Available from: http://www.seer.ufrgs.br/RevistaGauchadeEnfermagem/article/viewFile/4218/2228 Portuguese.

19. Cavalcanti KB. Pedagogia Vivencial Humanescente: para sentirpensar os sete saberes na educação. Curitiba: Editora CRV; 2010.

20. Camargo BV, Justo AM. [IRAMUTEQ: a free software for analysis of textual data]. Temas Psicol [Internet]. 2013 [cited 2016 Dec 02];21(2):5138. Available from: http://dx.doi.org/10.9788/TP2013.2-16 Portuguese.

21. Santos JLG, Lima MADS. [Care management: nurses' actions in a hospital emergency service]. Rev Gaucha Enferm [Internet]. 2011 [cited 2016 Dec 02];32(4):695-702. Available from: http://dx.doi.org/10.1590/S1983-14472011000400009 Portuguese.

22. Lima Neto AV, Nunes VMA, Fernandes RL, Barbosa IML, Carvalho GRP. Humanization and reception in hospital emergency: conditioning factors under the look of nurses. J Res Fundam Care online [Internet]. 2013 [cited 2016 Dec 05];5(4):519-28. Available from: http://dx.doi.org/10.9789/2175-5361.2013v5n4p519

23. Nascimento ERP, Silva SG, Souza BC, Souza DD, Germer Netto A. Environment of a hospital emergency unit for the elderly care: perception of nursing professionals. Esc Anna Nery [Internet]. 2015 [cited 2016 Dec 05];19(2):338-42. Available from: http://dx.doi. org/10.5935/1414-8145.20150046

24. Blegen MA, Goode CJ, Spetz J, Vaughn T, Park SH. Nurse staffing effects on patient outcomes: safety-net and non-safety-net hospitals. Med Care [Internet]. 2011 [cited 2016 Dec 10];49(4):406-14. Available from: http://dx.doi.org/10.1097/MLR.0b013e318202e129

25. Needleman J, Buerhaus P, Pankratz VS, Leibson CL, Stevens SR, Harris M. Nurse Staffing and inpatient hospital mortality. N Engl J Med [Internet]. 2011 [cited 2016 Dec 10];364(11):1037-45. Available from: http://dx.doi.org/10.1056/NEJMsa1001025

26. Santos JLG, Lima MADS, Pestana AL, Garlet ER, Erdmann AL. Challenges for the management of emergency care from the perspective of nurses. Acta Paul Enferm [Internet]. 2013 [cited 2016 Dec 10];26(2):136-43. Available from: http://dx.doi.org/10.1590/ S0103-21002013000200006

27. Silva EMR, Tronchin DMR. Reception of pediatric emergency room users from the perspective of nurses. Acta Paul Enferm [Internet]. 2011 [cited 2016 Dec 10];24(6):799-803. Available from: http://dx.doi.org/10.1590/S0103-21002011000600012

28. Cofen: Conselho Federal de Enfermagem. Resolução n. 376, de 24 de março de 2011. Dispõe sobre participação dos profissionais de enfermagem no transporte de pacientes em ambientes hospitalares. Brasília: COFEN; 2011.

29. Pedreira LC, Santos IM, Farias MA, Sampaio ES, Barros CSMA, Coelho ACC. [Nurses'knowledge of intra-hospital transport of critical patients]. Rev Enferm UERJ [Internet]. 2014 [cited 2016 Dec 10];22(4):533-9. Available from: http://www.facenf.uerj.br/v22n4/v22n4a16.pdf Portuguese.

30. Morais SA, Almeida LF. Por uma rotina no transporte intra-hospitalar: elementos fundamentais para a segurança do paciente crítico. Revista HUPE [Internet]. 2013 [cited 2016 Dec 10];12(3):138-46. Available from: http://dx.doi.org/10.12957/rhupe.2013.7541

31. Quadrado ERS, Tronchin DMR. Evaluation of the identification protocol for newborns in a private hospital. Rev Lat Am Enfermagem [Internet]. 2012 [cited 2016 Dec 11];20(4):659-67. Available from: http://dx.doi.org/10.1590/S0104-11692012000400005

32. Novaretti MCZ, Santos EV, Quitério LM, Daud-Gallotti RM. [Nursing workload and occurrence of incidents and adverse events in ICU patients]. Rev Bras Enferm [Internet]. 2014 [cited 2016 Dec 11];67(5):692-9. Available from: http://dx.doi.org/10.1590/0034-7167.2014670504

33. Johnson KD, Winkelman C. The effect of emergency department crowding on patient outcomes: a literature review. Adv Emerg Nurs J [Internet]. 2011 [cited 2016 Dec 11];33(1):39-54. Available from: http://dx.doi.org/10.1097/TME.0b013e318207e86a 